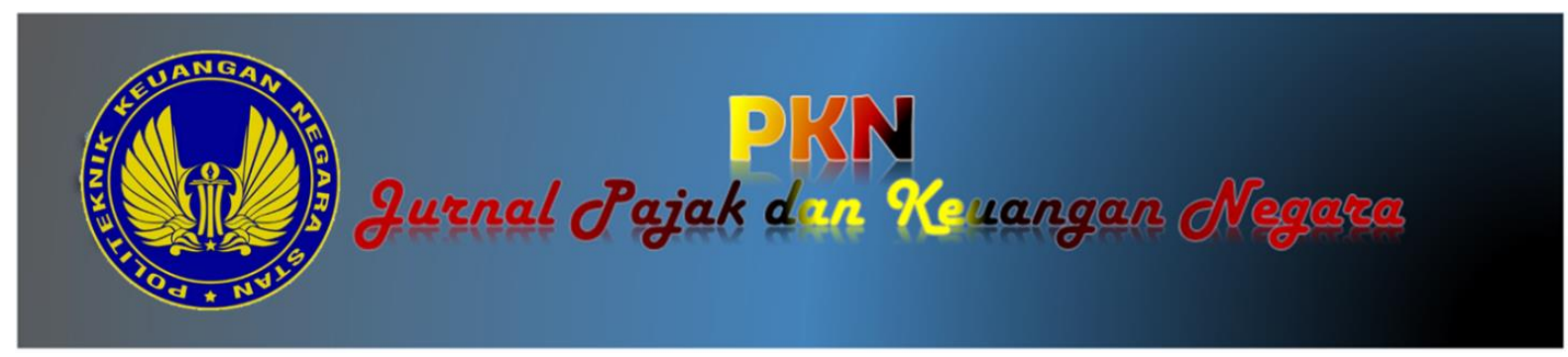

\title{
ANALISIS PENGENAAN PAJAK PENGHASILAN PASAL 15 TERHADAP KANTOR PERWAKILAN PERUSAHAAN ASING
}

\author{
Nurkholis Rafsanjani \\ Direktorat Jenderal Pajak, Kementerian Keuangan \\ Benny Gunawan Ardiansyah \\ Politeknik Keuangan Negara STAN, Kementerian Keuangan \\ Alamat Korespondensi: bennygunawan.ardiansyah@pknstan.ac.id
}

\section{INFORMASI ARTIKEL}

Diterima Pertama

[17 Mei 2021]

Dinyatakan Diterima

[28 06 2021]

KATA KUNCI:

PPh Pasal 15, Kantor Perwakilan Perusahaan Asing, Bentuk Usaha Tetap

KLASIFIKASI JEL:

K34

\begin{abstract}
There are some different interpretations of the application of Income Tax Article 15 regarding the Foreign Company Representative Office (KPPA). This happened due to undistinct provision regarding the definition and characteristics of the KPPA. This study tried to elaborate the characteristics of the representative offices for foreign companies in the taxation's perspectives. And then determining the imposition of Income Tax Article 15 based on the KPPA's existence. This study applied qualitative methods by identifying problems through preliminary studies and elaboration explained by a descriptive approach. Ang then examining in-depth interview to get the final conclusion. The results show that the characteristics of the representative offices for foreign companies should not meet the criteria for permanent establishment. However, many KPPAs operating in Indonesia have conceded the stipulated time limit and get economic flow. It means that KPPA get the income from the sale of goods by the head office of the representative office. Thus, the establishment of a representative office can be used as a mode for tax avoidance practices.

ABSTRAK
\end{abstract}

Terdapat perbedaan intepretasi penerapan PPh Pasal 15 terkait Kantor Perwakilan Perusahaan Asing (KPPA). Hal ini karena belum adanya ketentuan yang jelas terkait definisi dan karakteristik KPPA tersebut. Penelitian ini akan melakukan elaborasi bagaimana seharusnya karakteristik kantor perwakilan perusahaan asing dilihat dari sisi perpajakan serta bagaimana menentukan pengenaan PPh Pasal 15 terhadap keberadaan KPPA. Penelitian ini menggunakan metode kualitatif dengan melakukan identifikasi permasalahan melalui studi pendahuluan dan elaborasi dijelaskan dengan pendekatan deskriptif. Selanjutnya, dilakukan wawancara mendalam untuk mendapatkan kesimpulan. Hasil penelitian menunjukkan bahwa karakteristik kantor perwakilan perusahaan asing seharusnya tidak memenuhi kriteria BUT. Akan tetapi, KPPA yang beroperasi di Indonesia banyak yang melewati batas waktu yang ditentukan dan mendapatkan aliran ekonomi, berupa penghasilan dari penjualan barang oleh kantor pusat kantor perwakilan ke Indonesia. Dengan demikian, pembentukan suatu kantor perwakilan dapat dijadikan sebagai modus dalam melakukan praktik penghindaran pajak. 


\section{PENDAHULUAN}

Pasal 15 Undang-Undang Pajak Penghasilan menyatakan bahwa norma penghitungan khusus digunakan untuk menghitung penghasilan neto dari Wajib Pajak tertentu. Aturan tersebut dibuat untuk menghindari kesukaran dalam menghitung besarnya penghasilan kena pajak bagi Wajib Pajak tertentu; antara lain perusahaan pelayaran atau penerbangan internasional, perusahaan asuransi luar negeri, perusahaan pengeboran minyak, gas dan panas bumi, perusahaan dagang asing, serta perusahaan yang melakukan investasi dalam bentuk bangun-guna-serah (built, operate and transfer)

Peraturan pelaksanaan Pasal 15 UU PPh diatur dengan Keputusan Menteri Keuangan Nomor KMK634/KMK.04/1994 tentang Norma Penghitungan Khusus Penghasilan Neto bagi Wajib Pajak Luar Negeri yang Mempunyai Kantor Perwakilan Dagang di Indonesia dan Keputusan Direktur Jenderal Pajak Nomor KEP-667/PJ/2001 tentang hal yang sama dengan. Kedua keputusan tersebut memunculkan istilah baru: kantor perwakilan dagang. Selanjutnya terdapat penafsiran dalam SE-02/PJ.03/2008 tentang Penegasan atas Penerapan Norma Penghitungan Khusus Penghasilan Neto bagi Wajib Pajak Luar Negeri yang Mempunyai Kantor Perwakilan Dagang (Representative Office/Liaison Office) di Indonesia. Penegasan dilakukan terhadap kantor perwakilan dagang dipersamakan dengan representative office/ liaison office. Wajib Pajak luar negeri yang dimaksud adalah yang mempunyai Kantor Perwakilan Dagang (representative office/liaison office) di Indonesia, yang berasal dari negara yang belum mempunyai Persetujuan Penghindaran Pajak Berganda (P3B) dengan Indonesia.

Sejalan dengan perkembangan zaman, terdapat pengaturan lebih lanjut, sebagaimana tersebut dalam Surat Edaran Direktur Jenderal Pajak Nomor SE$60 / \mathrm{PJ} / 2013$, yang memunculkan istilah baru lagi : Kantor Perwakilan Perusahaan Asing, termasuk perwakilan dagang asing serta kantor perwakilan perusahaan asing. Secara eksplisit juga disebutkan bahwa Kantor Perwakilan Perusahaan Asing berbeda dengan Bentuk Usaha Tetap (BUT).

Pada praktiknya, terdapat suatu fakta di lapangan yang menunjukkan adanya sengketa (dispute) antara fiskus dan WP mengenai pelaksanaan ketentuan PPh Pasal 15. Sengketa tersebut dikarenakan terjadi perbedaan persepsi tentang karakteristik kantor perwakilan perusahaan asing, khususnya pembuktian status Bentuk Usaha Tetap. Beberapa putusan pengadilan pajak tentang sengketa pengenaan pasal 15 atas kantor perwakilan asing dapat dilihat pada tabeL 1 (lampiran) yang menunjukkan bahwa sebagian besar putusan pengadilan mengabulkan pemohonan yang diajukan oleh pemohon banding.
Terdapat beberapa perbedaan pandangan mengenai kriteria Wajib Pajak yang dikenai PPh Pasal 15 dan peraturan pelaksanaannya. Pandangan pertama menganggap bahwa kantor perwakilan harus memenuhi status BUT terlebih dahulu baru dapat dikenakan PPh Pasal 15. Sedangkan pandangan kedua berpendapat bahwa justru PPh Pasal 15 dikenakan atas Wajib Pajak yang bukan BUT.

Selain masalah sengketa, adanya perbedaan istilah terutama terkait pelaksanaan PPh Pasal 15 atas perusahaan perwakilan asing dengan peraturan pelaksanaannya dapat menimbulkan persepsi yang berbeda dalam pelaksanaan aturan tersebut. Belum adanya aturan yang jelas terkait definisi dan karakteristik kantor perwakilannya dapat menimbulkan persepsi yang berbeda dalam pelaksanaan aturan tersebut. Istilah Kantor Perwakilan Dagang yang muncul dari KMK Nomor 634/KMK.04/1994 belum didefinisikan dengan jelas mengenai bagaimana seharusnya suatu kantor perwakilan dagang dapat dikenai PPh Pasal 15.

Penelitian ini akan melihat ketiadaan definisi dan karakteristik yang jelas mengenai kantor perwakilan perusahaan asing serta adanya multitafsir atas pelaksanaan pengenaan pajaknya di Indonesia. Bagaimana seharusnya karakteristik kantor perwakilan perusahaan asing dilihat dari sisi perpajakan serta apa saja kriteria-kriteria dan kondisi-kondisi yang menyebabkan kantor perwakilan perusahaan asing dapat dikenakan PPh Pasal 15 akan dielaborasi lebih lanjut dengan penelitian ini.

\section{KERANGKA TEORI}

Pinto (2006) berpendapat bahwa hak yurisdiksi pajak berdasarkan manfaat yang telah diberikan negara kepada wajib pajak. Berdasarkan teori ini, negara harus memajaki individu sebagai timbal balik atas manfaat yang diberikan oleh negara kepada individu tersebut. Kontribusi berupa pajak tersebut merupakan hak yang diperoleh oleh negara terkait pelaksanaan pelayanan publik sebagai imbalan atas manfaat yang telah diberikan oleh negara. Dalam lingkup yang luas, manfaat tersebut tidak hanya diterima oleh warga negara tersebut, tetapi juga pada warga negara asing termasuk para pelaku usaha asing yang menjalankan bisnis di negara tersebut.

Sesuai dengan teori manfaat, kantor perwakilan dagang asing (KPDA) di Indonesia melakukan promosi dan kegiatan yang diharapkan membuat kantor pusat mendapatkan manfaat dari keberadaan KPDA tersebut sebagai hasil promosi di Indonesia. Manfaat-manfaat yang diterima oleh 
kantor pusat dari KPDA tersebut dapat berkaitan dengan keberlangsungan usaha dan bersifat material dalam konteks keuntungan bisnis, sehingga menurut Skaar (1991) entitas asing tersebut semestinya memberikan kontribusi berupa pajak kepada negara di mana entitas tersebut menjalankan usahanya.

Atas manfaat yang diterima oleh kantor pusat melalui KPDA di Indonesia, maka secara filosofis negara Indonesia berhak memajaki penghasilan yang diterima oleh kantor pusat tersebut.

\subsection{Kantor Perwakilan Perusahaan}

Investor asing pertam-tama akan menentukan badan hukum yang menjadi pilihan untuk berinvestasi di Indonesia. Pilihan terbaiknya adalah membentuk kantor perwakilan atau mendirikan entitas baru (Penanaman Modal Asing). Kantor Perwakilan mungkin menjadi cara yang efisien bagi investor asing sebelum mendirikan PMA. Kegiatan utama kantor perwakilan yang melakukan kegiatan penelitian penanda serta pemasaran dan promosi melalui menjual atau membeli agen. Pada tahap ini, seharusnya, masih bekum memberikan pendapatan langsung di bawah nama kantor perwakilan.

BKPM (2021) membagi klasifikasi kantor perwakilan dibagi ke dalam tiga jenis yaitu Kantor Perwakilan Perusahaan Asing, Kantor Perwakilan Perusahaan Perdagangan Asing dan Kantor Perwakilan Badan Usaha Jasa Konstruksi Asing. Pertama, Kantor Perwakilan Perusahaan Asing (KPPA) sebagaimana dijelaskan Pasal 1 angka 28:

“... kantor yang dipimpin oleh satu atau lebih perorangan warga negara asing atau warganegara Indonesia yang ditunjuk oleh perusahaan asing atau gabungan perusahaan asing di luar negeri sebagai perwakilannya di Indonesia."

Berdasarkan definisi tersebut maka suatu kantor perwakilan merupakan suatu perwakilan yang ditunjuk oleh kantor pusat perusahaan afiliasi di luar negeri, dan bisa dipimpin oleh WNI atauapun WNA.

Kegiatan Kantor Perwakilan Perusahaan Asing (KPPA) dibatasi kegiatannya, sesuai dengan yang diatur Pasal 22, meliputi mengurus kepentingan perusahaan atau perusahaan-perusahaan afiliasinya; dan/atau mempersiapkan pendirian dan pengembangan usaha perusahaan Penanaman Modal Asing, di Indonesia atau di negara lain dan Indonesia; dan berlokasi di ibukota provinsi dan beralamat di gedung perkantoran.

Jangka waktu Izin Kegiatan KPPA ditetapkan selama tiga tahun dan dapat diperpanjang sebanyak dua kali masing-masing satu tahun sehingga jangka waktu maksimal adalah lima tahun. Setelah periode jangka waktu lima tahun suatu KPPA dapat diberikan perpanjangan waktu kembali apabila kegiatan KPPA berbeda dengan kegiatan periode sebelumnya.
Kedua, Kantor Perwakilan Perusahaan Perdagangan Asing (KP3A) adalah perorangan WNI atau WNA yang ditunjuk oleh perusahaan asing atau gabungan perusahaan asing di luar negeri sebagai perwakilannya di Indonesia. Berdasarkan ketentuan Pasal 24, KP3A dapat berbentuk Agen Penjualan (Selling Agent) dan/atau Agen Pabrik (Manufactures Agent) dan/atau Agen Pembelian (Buying Agent) namun dilarang melakukan kegiatan perdagangan dan transaksi penjualan, baik dari tingkat permulaan sampai dengan penyelesaiannya seperti mengajukan tender, menandatangani kontrak, menyelesaikan klaim dan sejenisnya.

Ketiga, Kantor Perwakilan Badan Usaha Jasa Konstruksi Asing (BUJKA) dengan definisi berdasarkan Pasal 1 angka 30 yaitu:

"Kantor Badan Usaha Jasa dan Konstruksi Asing adalah badan usaha yang didirikan menurut hukum dan berdomisili di negara asing, memiliki kantor perwakilan di Indonesia, dan dipersamakan dengan badan hukum Perseroan Terbatas yang bergerak di bidang usaha jasa konstruksi."

Dengan demikian, status BUJKA dipersamakan dengan badan hukum Perseroan Terbatas yang bergerak di bidang usaha jasa konstruksi.

\subsection{Bentuk Usaha Tetap}

Subjek Pajak dibedakan menjadi subjek pajak dalam negeri dan subjek pajak luar negeri. Subjek Pajak Luar Negeri yang menerima atau memperoleh penghasilan menjadi Wajib Pajak Luar Negeri. Subjek pajak luar negeri, baik orang pribadi atau badan, dapat mebdirikan Bentuk Usaha tetap (BUT) untuk menjalankan usaha atau melakukan kegiatan di Indonesia. BUT ini kemudian berstatus subyek pajak dalam negeri.

Ketentuan yang menjadi dasar perlakuan perpajakan atas BUT diatur dalam Pasal 2 ayat (3) Undang-Undang Pajak Penghasilan, yakni :

"Bentuk usaha tetap adalah bentuk usaha yang dipergunakan oleh orang pribadi yang tidak bertempat tinggal di Indonesia, orang pribadi yang berada di Indonesia tidak lebih dari 183 (seratus delapan puluh tiga) hari dalam jangka waktu 12 (dua belas) bulan, dan badan yang tidak didirikan dan tidak bertempat kedudukan di Indonesia untuk menjalankan usaha atau melakukan kegiatan di Indonesia..."

Bentuk BUT meliputi tempat kedudukan manajemen; cabang perusahaan; kantor perwakilan; gedung kantor; pabrik; bengkel; gudang; ruang untuk promosi dan penjualan; pertambangan dan penggalian sumber alam; wilayah kerja pertambangan minyak dan gas bumi; perikanan, peternakan, pertanian, perkebunan, 
atau kehutanan; proyek konstruksi, instalasi, atau proyek perakitan; pemberian jasa dalam bentuk apa pun oleh pegawai atau orang lain, sepanjang dilakukan lebih dari enam puluh hari dalam jangka waktu dua belas bulan; orang atau badan yang bertindak selaku agen yang kedudukannya tidak bebas; agen atau pegawai dari perusahan asuransi yang tidak didirikan dan tidak bertempat kedudukan di Indonesia yang menerima premi asuransi atau menanggung risiko di Indonesia; dan komputer, agen elektronik, atau peralatan otomatis yang dimiliki, disewa, atau digunakan oleh penyelenggara transaksi elektronik untuk menjalankan kegiatan usaha melalui internet.

BUT di Indonesia sama dengan permanent establishment (PE) pada model OECD maupun model UN. Pasal 7 OECD Model mengatur bahwa prinsip dasar pemajakan untuk penghasilan usaha yaitu negara sumber hanya bisa memajaki penghasilan usaha sepanjang ada BUT yang terletak di negara sumber. Hak pemajakan negara sumber juga dibatasi sebesar laba yang diatribusikan kepada BUT tersebut.

Sementara itu, Kurniawan (2017) menyatakan bahwa konsep dasar dalam pemajakan atas penghasilan usaha berdasarkan prinsip "No PE No Tax" atau jika tidak ada BUT maka tidak ada pajak yang dapat dikenakan oleh negara sumber. Gunadi (2007) menambahkan bahwa secara hukum, BUT dan kantor pusatnya adalah satu kesatuan yang tidak terpisah. Hanya untuk keperluan administrasi perpajakan saja mereka dianggap seolah-olah merupakan entitas yang terpisah.

Objek pajak bagi BUT diatur dalam Pasal 5 ayat (1) UU PPh meliputi penghasilan dari usaha atau kegiatan bentuk usaha tetap tersebut dan dari harta yang dimiliki atau dikuasai; penghasilan kantor pusat dari usaha atau kegiatan, penjualan barang, atau pemberian jasa di Indonesia yang sejenis dengan yang dijalankan atau yang dilakukan oleh bentuk usaha tetap di Indonesia; penghasilan sebagaimana tersebut dalam Pasal 26 yang diterima atau diperoleh kantor pusat, sepanjang terdapat hubungan efektif antara bentuk usaha tetap dengan harta atau kegiatan yang memberikan penghasilan tersebut.

Dalam Pasal 2 ayat (1a) UU PPh dijelaskan bahwa perlakuan perpajakan atas BUT dipersamakan dengan subjek pajak badan.

\subsection{Perlakuan Pajak terhadap Kantor Perwakilan Perusahaan Asing}

PPh Pasal 15 adalah Pajak Penghasilan yang dikenakan atas penghasilan yang diterima atau diperoleh oleh Wajib Pajak tertentu. Dalam undangundang, terdapat banyak pasal yang mengatur pajak penghasilan atau PPh. Sama seperti pajak penghasilan (PPh) lainnya, PPh 15 juga memiliki objek pajak dalam bentuk penghasilan. Perbedaan yang paling mendasar terletak pada perhitungan serta berapa persentase yang harus dibayarkan untuk setiap jenis objek pajak yang ditentukan. Terdapat norma penghitungan khusus untuk golongan Wajib Pajak tertentu, antara lain perusahaan pelayaran atau penerbangan internasional, perusahaan asuransi luar negeri, perusahaan pengeboran minyak, gas dan panas bumi, perusahaan dagang asing, perusahaan yang melakukan investasi dalam bentuk bangun-gunaserah (build, operate, and transfer).

Aturan pelaksanaan dari Pasal 15 Undangundang PPh bagi Perusahaan Dagang Asing yang mempunyai Kantor Perwakilan Dagang di Indonesia yaitu Keputusan Menteri Keuangan Nomor 634/KMK.04/1994 tentang Norma Penghitungan Khusus Penghasilan Neto Bagi Wajib Pajak Luar Negeri yang Mempunyai Kantor Perwakilan Dagang di Indonesia yang pelaksanaannya diatur lebih lanjut dengan Keputusan Direktur Jenderal Pajak Nomor KEP667/PJ./2001 tentang Norma Penghitungan Khusus Penghasilan Neto Bagi Wajib Pajak Luar Negeri yang Mempunyai Kantor Perwakilan Dagang di Indonesia.

\subsection{Perlakuan Perpajakan Representative Office di Beberapa Negara Asia}

Perlakuan perpajakan atas kantor perwakilan di negara lain pada umumnya hampir sama, yaitu tidak dikenai pajak selama kantor perwakilan tersebut tidak menghasilkan penghasilan dari negara tempat perwakilan tersebut berada. Di Singapura, atas representative office tidak dikenai pajak penghasilan karena tidak ada penghasilan yang dihasilkan oleh representative office (Inland Revenue Authority of Singapore, 2021).

Sedangkan di China terdapat aturan atas pemajakan representative office yang dikeluarkan oleh PRC State Administration of Taxation yang berlaku efektif per Januari 2010 sesuai yang dikutip dari Cheung dan Jiang (2013). Setiap representative office harus membayar pajak kecuali atas kantor perwakilan yang memiliki persetujuan penghindaran pajak berganda dengan pemerintah China. Atas penghasilan tersebut dapat dikenakan EIT (Enterprise Income Tax) jika memiliki tiga bentuk penghasilan.

Pertama, actual amount method, jika representative office tadi memiliki catatan yang lengkap atas penghasilan dan pengeluaran, dihitung sesuai dengan aturan pajak penghasilan badan yang berlaku meskipun representative office tersebut tidak menghasilkan profit seperti kegiatan bisnis tradisional pada umumnya, yang dinilai dari jasa yang mereka berikan. 
Kedua, actual-revenue-deemed method, yang menggunakan suatu perhitungan khusus yang mirip dengan norma perhitungan, digunakan jika diketahui perkiraan pendapatan namun pengeluaran tidak diketahui. Dan ketiga, cost-plus method, jika catatan penghasilan tidak lengkap namun catatan pengeluaran lengkap.

Sedangkan di India, liaison office bukan merupakan subjek pajak dikarenakan tidak ada mekanisme dari otoritas pajak India untuk memeriksa dan menentukan bahwa aktivitas liaison office menghasilkan suatu penghasilan (Government of India, 2021). Namun liaison office tetap diwajibkan untuk memungut pajak dari pembayaran tertentu yang disesuaikan menurut undang-undang pajak India.

Sementara itu, berdasarkan Thailand Board of Investment (202) mengatur bahwa representative office tidak dianggap sebagai subjek pajak namun wajib memiliki tax identification number atau NPWP dan wajib untuk melaporkan SPT Tahunan meskipun nihil. Terakhir di Filipina, representative office dianggap sebagai cost center dan bukan merupakan subjek pajak penghasilan namun merupakan subjek pajak atas kewajiban witholding taxes yang muncul.

\section{METODE PENELITIAN}

Penelitian ini menggunakan metode kualitatif dengan melakukan identifikasi permasalahan melalui studi pendahuluan, sehingga objek penelitian menjadi lebih luas. Beberapa permasalahan akan dijelaskan dengan pendekatan deskriptif yang bertujuan untuk memberikan suatu gambaran dengan menggunakan kata maupun angka dan untuk menyajikan profil, klasifikasi jenis, atau garis besar dari langkah-langkah guna menjawab mengenai apa, mengapa, di mana, dan bagaimana.

Analisis dilakukan dengan menggunakan pendekatan pendekatan induktif yaitu proses di mana peneliti mengamati fenomena tertentu guna, berdasarkan hal tersebut, akhirnya tiba pada kesimpulan akhir (Sekaran dan Bougie, 2016).

\subsection{Pengumpulan dan Analisis Data}

Peneliti melakukan analisis data berdasarkan Neuman (2014) yang menggunakan tiga metode untuk mengolah data kualitatif. Pertama penyandian data dan pembentukan konsep, yang memfokuskan pada penyusunan data dalam satu rangkaian pokok bahasan utama melalui proses open coding, axial coding, dan selective coding.

Kedua, melakukan penulisan memo analitis, yang mendokumentasikan dan menyusun berdasarkan kode data yang telah ditetapkan sebelumnya. Dan ketiga, outcropping, yaitu menganalisis untuk mendapatkan pemahaman yang utuh mengenai jawaban dari masalah yang diteliti. Pemahaman tersebut disimpulkan dengan melihat kembali bukti empiris yang telah disusun sebelumnya.

\subsection{Sumber Data Penelitian dan Informan}

Penelitian ini akan melihat situasi penelitian secara lebih mendalam melalui wawancara mendalam (in-depth interview) secara tatap muka. Sehingga menggunakan triangulasi sumber yang terdiri dari pembuat peraturan, pengguna langsung peraturan, dan akademisi. Sumber data pada penelitian ini yaitu dari para informan. Data diperoleh melalui wawancara kepada pihak-pihak yang merupakan otoritas pembuat peraturan, terdiri dari pegawai Direktorat Peraturan Perpajakan I, Peraturan Perpajakan II dan Direktorat Pajak Internasional.

Sementara itu, pengguna langsung aturan adalah patugas administrasi pajak dari Kantor Pelayanan Pajak Badan dan Orang Asing. Pihak Wajib Pajak diwakili oleh Konsultan Pajak Danny Darussalam Tax Centre dan dari pihak Ortax Indonesia. Sedangkan dari pihak akademisi, dilakukan terhadap Widyaiswara pada Kementerian Keuangan dan dosen Universitas Indonesia.

Skema analisis penelitian ini dapat dilihat pada gambar 1 berikut:

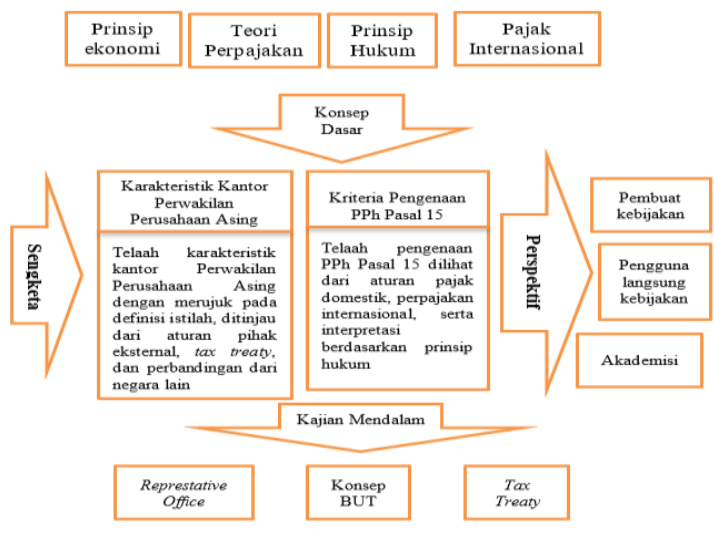

Gambar 1 Skema Analisis

Sumber: Diolah oleh penulis

\section{HASIL PENELITIAN}

\subsection{Karakteristik Kantor Perwakilan Perusahaan} Asing

Saat pelaksanaan wawancara, penulis mencoba menyarikan karakterisik kantor perwakilan perusahaan asing dengan mendikotomikannya menjadi kantor perwakilan perusahaan asing berstatus BUT dan kantor perwakilan perusahaan asing yang bukan merupakan BUT. 
Karakteristik kantor perwakilan perusahaan asing dari sisi perpajakan dapat diturunkan berdasarkan karakterisik kantor perwakilan perusahaan asing berdasarkan aturan BKPM, karakteristik yang dikecualikan sebagai permanent establishment menurut peraturan pajak internasional/persetujuan penghindaran pajak berganda (P3B), serta beberapa perbandingan karakteristik kantor perwakilan perusahaan asing dari berbagai negara dan dilihat juga dari pembagian jenis Wajib Pajak Badan menurut SE-60/PJ/2013. Hasil penelitian Kusuma (2019) menunjukkan bahwa: “... Beberapa hal berkaitan dengan Kantor Perwakilan Perusahaan Asing (KPPA), hanya diperbolehkan melakukan kegiatan sebatas pada peranannya sebagai pengawas, penghubung, koordinator dan mengurus kepentingan perusahaan atau perusahaan-perusahaan afiliasi di Indonesia dan atau negara di luar Indonesia. KPPA tidak diperkenankan untuk mencari penghasilan yang bersumber dari Indonesia, termasuk tidak dibenarkan melaksanakan kegiatan atau melakukan sesuatu perikatan/transaksi penjualan dan pembelian barang dan jasa dengan perusahaan atau perorangan di dalam negeri..."

Sementara itu, hasil wawancara menyatakan bahwa berdasarkan karakteristiknya :

a) Status KPPA dan KP3A merupakan non-BUT sebagaimana ketentuan yang diatur oleh BKPM. Rincian karakteristik adalah terkait aktivitas kantor perwakilan berupa mengurus kepentingan perusahaan atau perusahaan-perusahaan afiliasi dan mempersiapkan pendirian perusahaan dan pengembangan usaha Penanaman Modal Asing di Indonesia. Selain itu karakteristik dilarang melakukan kegiatan perdagangan dan penjualan seperti menandatangai kontrak menurut beberapa narasumber merupakan hal yang penting dan dapat dijadikan karakteristik kantor perwakilan perusahaan asing dari perspektif perpajakan.

b) Kantor perwakilan perusahaan asing termasuk dikecualian sebagai BUT menurut P3B masingmasing negara. Aturan P3B, yang sejalan dengan OECD Model, telah memberikan beberapa kriteria-kriteria yang dapat dipakai sebagai dasar penentukan karakteristik. Dalam penjelasan UU PPh Pasal 32A bahwa dalam rangka peningkatan hubungan ekonomi dan perdagangan dengan negara lain diperlukan suatu perangkat hukum yang berlaku khusus (lex-specialis).

Dengan menggunakan metode perbandingan analitis menurut Neuman (2014) maka hasil ihtisar dapat dilihat pada gambar 2 :

\begin{tabular}{|c|} 
Karakteristik \\
dari BKPM
\end{tabular}$\square \begin{gathered}\begin{array}{c}\text { Karakteristik dari } \\
\text { Rep. Off. Negara } \\
\text { lain }\end{array} \\
\text { Karakteristik cfm tax } \\
\text { treaty }\end{gathered}$

- Mengurus kepentingan
perusahaan atau
perusahaan afiliasi;
- Mempersiapkan
pendirian dan
pengembangan usaha
perusahaan PMA di
Indonesia atau di negara
lain dan Indonesia; dan
- Berlokasi di ibukota
provinsi dan beralamat
di gedung perkantoran

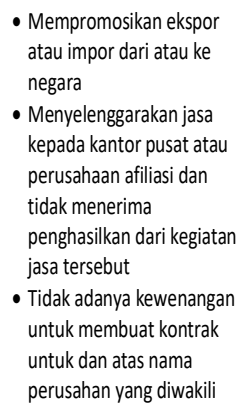

Karakteristik sebagai non-BUT

Mengurus kepentingan perusahaan atau perusahaan-perusahaan afiliasi, menjalankan dan kepentingan perusahaan dan aktivitas lain yang bersifat penunjang atau persiapan, tidak adanya kewenangan untuk membuat kontrak untuk dan atas nama perusahaan yang diwakili, berkegiatan di Indonesia, menyelenggarakan jasa kepada kantor pusat atau perusahaan afiliasi dengan tidak mendapat penghasilan dari kegiatan jasa tersebut, atau dalam hal kantor perwakilan berasal dari perusahaan yang berkedudukan di negara yang memiliki perjanjian.

Gambar 2 Analisis Karakteristik KPPA

Sumber: Diolah dari hasil wawancara

Terdapat beberapa karakteristik kantor perwakilan perusahaan asing yang bukan sebagai BUT yang dapat dilihat pada bagian terbawah gambar 2, yaitu (i) mengurus kepentingan perusahaan atau perusahaan-perusahaan afiliasi; (ii) menjalankan dan kepentingan perusahaan dan aktivitas lain yang bersifat penunjang atau persiapan; (iii) tidak adanya kewenangan untuk membuat kontrak untuk dan atas nama perusahaan yang diwakili; (iv) berkegiatan di Indonesia; (v) menyelenggarakan jasa kepada kantor pusat atau perusahaan afiliasi dengan tidak mendapat penghasilan dari kegiatan jasa tersebut, atau (vi) dalam hal kantor perwakilan berasal dari perusahaan yang berkedudukan di negara yang memiliki perjanjian P3B dengan Indonesia, maka kantor perwakilan tidak dianggap sebagai BUT.

\subsection{Kriteria Pengenaan Pajak Penghasilan Pasal 15 atas Kantor Perwakilan Perusahaan Asing}

UU PPh Pasal 15 mengatur bahwa Norma Penghitungan Khusus untuk menghitung penghasilan neto dari Wajib Pajak tertentu yang tidak dapat dihitung berdasarkan ketentuan Pasal 16 ayat (1) atau (3) ditetapkan oleh Menteri Keuangan. Penjelasan pasal tersebut menyebutkan salah satu WP tertentu adalah perusahaan dagang asing dan menjadi dasar 
pengenaan PPh pasal 15 atas Kantor Perwakilan Dagang Asing.

Peraturan pelaksanaannya diatur dalam Keputusan Menteri Keuangan Nomor 634/KMK.04/ 1994 yang menggunakan istilah berbeda. Alih-alih menggunakan istilah perusahaan dagang asing, KMK tersebut justru menyebutkan istilah baru: kantor perwakilan dagang tanpa adanya penjelasan sama sekali mengenai definisi maupun karakteristiknya. Tidak dijelaskan mengenai status BUT maupun nonBUT terkait kantor perwakilan dagang tersebut. Hal tersebut membuat multitafsir mengenai apakah PPh Pasal 15 tersebut dikenai atas Kantor Perwakilan Dagang yang merupakan BUT atau yang non-BUT.

Pengaturan selanjutnya dapat dilihat pada KEP667/PJ/2001 yang menyebutkan bahwa penerapan norma penghitungan khusus penghasilan neto bagi Wajib Pajak luar negeri yang mempunyai Kantor Perwakilan Dagang (representative office/liaison office) di Indonesia. Kantor perwakilan dagang dipersamakan dengan representative office/ liaison office.

Berdasarkan pembahasan sebeumnya setidaknya terdapat dua hal yang membatasi aktivitas KPPA : tidak ada aliran penghasilan dan pembatasan jangka waktu selama-lamanya lima tahun. KPPA dapat diberikan perpanjangan waktu jika aktivitas KPPA berbeda dengan kegiatan periode sebelumnya. Berdasarkan hasil penelitian Tarsingot (2014) menyimpulkan bahwa

“...penanaman modal asing di Indonesia harus dalam bentuk Perseroan Terbatas (PT). Akan tetapi pada tataran peraturan pelaksana, investor asing dalam hal ini perusahaan asing dapat menanamkan modalnya di Indonesia dalam bentuk selain PT yaitu dengan mendirikan kantor perwakilan dan/atau cabang di Indonesia. Pada awalnya kantor perwakilan dan/atau cabang berfungsi sebagai perintis untuk dibentuknya PT, tapi pada praktiknya banyak kantor perwakilan dan/atau cabang yang terus berdiri sejak tahun 1960-an hingga sekarang...."

KMK No. 634/KMK.04/1994 pun menyiratkan bahwa Wajib Pajak luar negeri yang mempunyai kantor perwakilan dagang di Indonesia memiliki kemungkinan untuk menerima penghasilan dari penyerahan barang kepada orang pribadi atau badan yang berada atau bertempat kedudukan di Indonesia.

Berdasarkan hasil wawancara, mayoritas narasumber mengatakan bahwa pengenaan PPh Pasal 15 dapat dikenai atas KPPA dan KPDA. Dua narasumber mengatakan bahwa hanya KPDA saja yang dapat dikenai PPh Pasal 15 karena yang diatur hanya KPDA saja. Jika ditinjau dari aturan pajak domestik maupun internasional maka kedua-duanya dapat dikenai PPh Pasal 15 selama keduanya memenuhi definisi BUT dari P3B jika kantor pusat dari perwakilan tersebut memiliki P3B dengan Indonesia.
Pengenaan PPh Pasal 15 atas kantor perwakilan dagang asing terkait status BUT dan non-BUT merupakan hal yang menjadi perdebatan di lapangan. Dari sembilan narasumber, tujuh narasumber berpendapat bahwa dalam mengenakan PPh Pasal 15 atas KPDA, hanya untuk BUT. Dua narasumber mengatakan justru non-BUT yang dikenai Pasal 15. Aturan domestik terkait PPh Pasal 15 berdasarkan perlakuan perpajakan dapat dilihat pada Gambar 3.

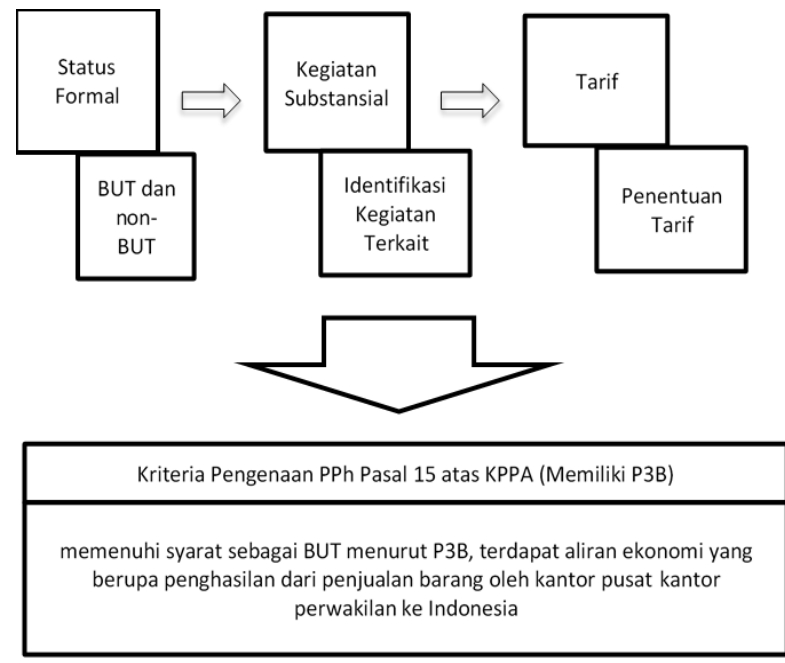

Gambar 3 Analisis Kriteria Pengenaan PPh Pasal 15 Sumber: Diolah dari hasil wawancara

Berdasarkan uraian hasil wawancara narasumber dapat disimpulkan bahwa kriteria pengenaan PPh Pasal 15 terhadap kantor perwakilan perusahaan asing adalah:

Pertama, apabila terdapat P3B antara Indonesia dengan negara asal kantor pusat dari kantor perwakilan perusahaan asing maka kantor perwakilan perusahaan asing harus memenuhi syarat sebagai BUT menurut P3B. Jika tidak memenuhi kriteria pertama (atau tidak terdapat P3B) maka akan langsung dianggap sebagai Subyek Pajak Luar Negeri.

Kedua, keharusan adanya aliran ekonomi yang berupa penghasilan berupa penjualan barang oleh kantor pusat kantor perwakilan ke Indonesia.

\subsection{Fisibilitas Pemajakan KPPA Digital Ekonomi}

Berdasarkan hasil wawancara, pengenaan PPh Pasal 15 atas perusahaan berjenis KPPA yang bercirikan teknologi tersebut memang tidak fisibel. $\mathrm{Hal}$ ini belum adanya aturan yang mengatur topik tersebut dan juga secara konsep PPh Pasal 15 atas kantor perwakilan ditujukan untuk kantor perwakilan yang kantor pusatnya melakukan kegiatan penjualan barang, bukan penyerahan jasa. 
Sedangkan jenis pajak yang fisibel adalah dengan mengenakan PPN karena pengenaan PPN tidak dibatasi hak pemajakannya oleh treaty. Ketiga pihak, baik pelaksana aturan, pembuat aturan, dan akademisi sepakat bahwa pengenaan pemajakan atas KPPA perusahaan berjenis teknologi ini susah untuk dilaksanakan. Disamping aturan yang belum ada, permasalahan terkait hal ini juga merupakan isu internasional yang membutuhkan konsensus dalam menentukan sikap dan pandangan.

Saat ini memang Indonesia belum memiliki alat peraturan untuk memajaki kantor perwakilan asing yang berjenis perusahaan digital karena Indonesia dibatasi oleh treaty dalam hak pemajakan. Diperlukan suatu upaya misalnya negosiasi ulang atas treaty walaupun kelemahannya yaitu proses renegosisasi treaty membutuhkan waktu yang cukup lama. Hal yang mungkin dapat DJP lakukan adalah membuat suatu peraturan baru di luar treaty, membuat suatu pungutan baru, pajak baru yang ditujukan kepada pemajakan atas penghasilan dari jasa periklanan yang diterima oleh perusahaan-perusahaan yang memanfaatkan digital ekonomi.

Indonesia telah mengeluarkan kebijakan terkait dengan penerapan Pajak Penghasilan atas kegiatan Penyelenggara Perdagangan Melalui Sistem Elektronik (PMSE) atau Pajak Transaksi Elektronik melalui Undang-Undang Nomor 2 Tahun 2020. Peraturan tersebut merupakan payung hukum bagi Indonesia untuk dapat mengenakan Pajak terhadap PPMSE, khususnya bagi Subjek Pajak Luar Negeri.

\subsection{Modus Penghindaran Pajak}

Pendirian kantor perwakilan perusahaan asing merupakan langkah yang dilakukan oleh perusahaan multinasional dalam melakukan ekspansi usaha. Ekspansi tersebut dilakukan oleh beberapa faktor menurut Achtar (1994), yaitu ruang lingkup pasar yang terbatas dinegara asal perusahaan; biaya produksi yang cenderung semakin besar akibat komponen biaya yang relatif mahal seperti upah tenaga kerja yang semakin tinggi, yang berakibat produk kurang memiliki daya saing tinggi.

Salah satu langkah yang dilakukan oleh perusahaan multinasional tersebut adalah dengan memindahkan lokasi usaha ke negara lain. Munculnya kantor perwakilan perusahaan asing (representative office/liaison office) di Indonesia merupakan suatu bentuk langkah yang dilakukan oleh perusahan multinasional tersebut. Namun tidak tertutup kemungkinan bahwa pendirian kantor perwakilan perusahaan asing tersebut merupakan suatu cara yang digunakan guna mendapatkan manfaat ekonomis dari suatu negara dengan meminimalkan atau menghindari pajak. Hal ini cukup beralasan karena pada umumnya, representative office tidak dikenakan pajak penghasilan dari negara sumber karena dianggap bukan sebagai permanent establishment atau suatu BUT.

Kegiatan kantor perwakilan asing baik yang mengurus kepentingan perusahan dan perusahaan afiliasi yang terlalu lama dapat dipertanyakan apakah kegiatan yang dilakukan tersebut masih merupakan kegiatan persiapan atau penunjang (preparatory or auxilary) atau sudah termasuk dalam kegiatan yang menghasilkan pendapatan. Hal inilah yang merupakan celah yang dapat dimanfaatkan oleh Wajib Pajak dalam melakukan penghindaran pajak. Dalam hal ini maka Indonesia akan dirugikan karena sebenarnya terdapat potensi penerimaan yang dapat diterima namun tidak dapat dikenai pemajakan karena dibatasi oleh aturan treaty.

Pihak Otoritas Pajak Indonesia menengarai terdapat kantor perwakilan yang hanya berizin sebagai kantor perwakilan, namun dari laman resminya terdapat informasi bahwa ada kewenangan dari kantor perwakilan tersebut dalam menandatangai kontrak. Hal ini sudah melenceng dari pengecualian sebagai BUT menurut OECD Model sehingga kantor perwakilan tersebut harus ditetapkan sebagai BUT. Hanya saja pembuktian tersebut tidak mudah, perlu upaya ekstra dari pihak fiskus guna membuktikan kegiatan kantor perwakilan dapat ditetapkan sebagai BUT.

\subsection{Analisis Sengketa Pajak atas Pengenaan PPh Pasal 15 terhadap Kantor Perwakilan Perusahaan Asing}

Sengketa pajak timbul ketika ada perbedaan pendapat antara Wajib Pajak dan Fiskus. Berdasarkan data, kasus sengketa PPh Pasal 15 atas Kantor Perwakilan Dagang lebih banyak dimenangkan oleh Wajib Pajak. Dari Putusan Pengadilan Pajak (2021) menyebutkan bahwa atas putusan banding yang terbit tiga tahun terakhir menunjukkan bahwa 45 dari 48 kasus putusan banding dimenangkan oleh pihak Wajib Pajak. Meskipun, masih terdapat sengketa yang dimenangkan oleh DJP, tetapi perlu dilakukan evaluasi dalam melakukan pengenaan PPh Pasal 15 atas Kantor Perwakilan Dagang. hasil analis beberapa contoh sengketa yang menghasilkan dua putusan: menerima seluruhnya pemohon banding dan menolak permohonan pemohon banding adalah sebagai berikut:

1) Put.76029/PP/M.VIA/27/2016

Sengketa terjadi atas kantor perwakilan perusahaan perdagangan asing dari negara India yang dikenai PPh Pasal 15 oleh DJP. Pemohon banding berargumen bahwa pihaknya bukan merupakan Bentuk Usaha Tetap karena sesuai pasal 5 ayat 3 P3B Indonesia dengan India kegiatan 
periklanan, pemberian keterangan, dan riset ilmiah merupakan kegiatan yang dikecualikan sebagai BUT sehingga sesuai $\mathrm{P} 3 \mathrm{~B}$ antara Indonesia dengan India, maka Indonesia tidak berhak memungut pajak kepada pemohon banding.

DJP memiliki data berupa nilai ekspor bruto yang diperoleh dari PIB perusahaan Indonesia dan data di portal pertukaran data DJP dan DJBC. DJP beragumen bahwa pemohon banding merupakan BUT karena melakukan aktivitas memperkenalkan dan memajukan pemasaran barang-barang yang dihasilkan oleh grupnya secara aktif yaitu dengan melakukan pertemuan dengan calon konsumen di Indonesia, yang artinya melakukan kegiatan sebagaimana lazimnya kantor pusat. Majelis berpendapat bahwa aktivitas pemohon banding yakni mempromosikan poduk bukanlah aktivitas penunjang, namun melainkan hal yang sangat penting bagi perusahaan secara keseluruhan dan mencerminkan kegiatan perusahaan (kantor pusat) yaitu melakukan fungsi marketing produk yang memiliki pasar sangat spesifik dan sempit di Indonesia. Promosi yang dilakukan terbukti berkontribusi dalam menciptakan laba/ penjualan bagi kantor pusat yang dilihat dari realisasi ekspor barang dari India ke Indonesia secara berkelanjutan. Kegiatan dari pemohon banding juga tidak bersifat sementara karena telah berlangsung lama bertahun-tahun dan berkelanjutan. Selain itu pemohon banding memiliki tempat usaha permanen di Jakarta. Hal tersebut membuat majelis berpendapat bahwa pemohon banding merupakan BUT menurut P3B Indonesia dengan India.

Selain itu menurut OECD Model, pemohon banding sudah memenuhi kondisi untuk disebut sebagai permanent establishment. Kesimpulan majelis yaitu pemohon banding merupakan BUT baik berdasarkan ketentuan domestik, UU PPh, maupun OECD Model dan P3B. Atas dasar tersebut, koreksi dari pihak terbanding (DJP) tetap dipertahankan.

Berdasarkan narasi tersebut, sengketa tersebut dimenangkan oleh DJP karena DJP memiliki bukti yang kuat bahwa pemohon banding dapat disebut sebagai BUT menurut ketentuan P3B. Sehingga atas pemajakan yang dilakukan oleh DJP secara domestik tidak dibatasi oleh P3B karena sudah memenuhi ketentuan BUT menurut P3B. Hal tersebut selaras dengan hasil wawancara penulis terkait penentuan BUT bagi suatu kantor perwakilan asing yaitu dilihat dari aspek tempat usaha tetap dan substansi kegiatan yang menyimpang dari fungsi persiapan dan penunjang menurut P3B. Pembuktian kegiatan yang menyimpang dari fungsi persiapan dan penunjang ini yang menjadi tantangan bagi DJP dalam mengenakan PPh Pasal 15 atas Kantor Perwakilan Dagang. Hal yang dibutuhkan sebagai pembuktian kuat status BUT yaitu tidak hanya dari nilai ekspor bruto dari pertukaran data DJP dan DJBC tetapi juga dilihat dari substansi kegiatan kantor perwakilan dagang jika dibandingkan dengan kegiatan kantor pusat yang dianggap menyimpang dari fungsi persiapan dan penunjang.

2) Put.70628/PP/M.VIIIB/27/2016

Dalam sengketa ini, pemohon banding (Wajib Pajak) berasal dari negara Amerika Serikat. Argumen DJP dalam mengenakan PPh Pasal 15 adalah adanya data nilai ekspor bruto menurut KMK 634/KMK.04/1994 yang berasal dari pertukaran data DJP dan DJBC. Selain itu, pemohon banding dianggap menjadi BUT oleh DJP karena telah memenuhi persyaratan suatu tempat usaha tetap berupa kantor di Jakarta, selain itu Wajib Pajak telah terdaftar sejak tahun 1995 dan telah mengalami perpanjangan izin usaha perwakilan sebanyak 12 kali sehingga dianggap telah melakukan kegiatan usaha secara terus menerus dan tidak diketahui kapan akan berhenti beroperasi. Pemohon banding dianggap telah melakukan kegiatan usaha berupa aktivitas pemasaran dan riset pemasaran bagi pihak lain. Kegiatan pemasaran tersebut dianggap pemasaran aktif yang bukan semata-mata pengiklanan atau pemberian pemasaran sehingga dianggap sebagai bukan ativitas persiapan dan penunjang yang menghasilkan penjualan bagi kantor pusat. Hal tersebut yang menjadi argumen DJP bahwa pemohon banding merupakan BUT menurut P3B Indonesia-Amerika. Argumen pemohon banding adalah bahwa pemohon banding bukan BUT menurut P3B Indonesia-Amerika. Pemohon banding berargumen bahwa status di Indonesia merupakan kantor perwakilan yang dikecualikan sebagai BUT menurut P3B. Selain itu pemohon banding juga berargumen bahwa kegiatan di Indonesia hanyalah aktivitas penunjang berupa memperkenalkan dan menunjukkan produk kantor pusat, memberikan keterangan produk, serta riset pasar.

Majelis berpendapat bahwa berdasarkan buktibukti yang ada, kegiatan yang dilakukan oleh pemohon banding memang merupakan kegiatan yang bersifat penunjang dan bukan kegiatan yang menimbulkan BUT menurut P3B. Majelis berpendapat bahwa DJP tidak dapat membuktikan pemohon banding terlibat secara langsung atas penjualan produk kantor pusat di Indonesia berdasar data PIB. Atas dasar tersebut, permohonan pemohon banding dikabulkan seluruhnya.

Kedua kasus sengketa atas pengenaan PPh Pasal 15 terhadap kantor perwakilan asing tersebut memang tidak sederhana. Sengketa tersebut merupakan sengketa terkait subjek pajak yaitu terkait pembuktian BUT dan non-BUT. Baik pihak WP maupun DJP telah memiliki argumen 
tersendiri dalam menentukan BUT yang masuk dalam pengertian P3B. Hanya saja memang dalam kasus ini, pembuktian atas kegiatan kantor perwakilan yang bukan sebagai persiapan atau penunjang merupakan titik kritis yang menyebabkan suatu kantor perwakilan dapat dikatakan sebagai BUT menurut P3B. Pembuktian tersebut bukanlah hal yang mudah karena harus melalui penelitian terkait fungsi, aset, dan risiko dari kegiatan kantor perwakilan dibandingkan dengan kantor pusatnya.

\section{KESIMPULAN DAN SARAN}

Berdasarkan hasil pembahasan, maka dapat diambil dua kesimpulan, yakni

Pertama, berdasarkan tujuan utama pendirian kantor perwakilan perusahaan asing adalah

i. mengurus kepentingan perusahaan atau perusahaan-perusahaan afiliasi;

ii. menjalankan dan kepentingan perusahaan dan aktivitas lain yang bersifat penunjang atau persiapan;

iii. tidak adanya kewenangan untuk membuat kontrak untuk dan atas nama perusahaan yang diwakili;

iv. berkegiatan di Indonesia;

v. menyelenggarakan jasa kepada kantor pusat atau perusahaan afiliasi dengan tidak mendapat penghasilan dari kegiatan jasa tersebut, atau

vi. dalam hal kantor perwakilan berasal dari perusahaan yang berkedudukan di negara yang memiliki perjanjian P3B dengan Indonesia, maka kantor perwakilan tidak dianggap sebagai BUT.

Kedua, kriteria pengenaan PPh Pasal 15 terhadap kantor perwakilan perusahaan asing adalah:

i. Apabila terdapat P3B antara Indonesia dengan negara asal kantor pusat dari kantor perwakilan perusahaan asing maka harus memenuhi syarat sebagai BUT menurut P3B.

Jika tidak terdapat P3B, maka akan langsung dianggap sebagai Subyek Pajak Luar Negeri.

ii. Keharusan adanya aliran ekonomi yang berupa penghasilan berupa penjualan barang oleh kantor pusat kantor perwakilan ke Indonesia.

Berdasarkan kedua kesimpulan tersebut, maka seharusnya aturan pajak domestik yang mengatur mengenai pelaksanaan PPh Pasal 15 selayaknya perlu dikaji ulang mengingat terdapat aturan yang sudah berlaku lebih dari dua dekade dan banyak menimbulkan multitafsir di lapangan. DJP perlu untuk merevisi aturan pelaksanaan PPh Pasal 15 terutama pada KMK 634/KM.04/1994 terutama dari segi pendefinisian kantor perwakilan dagang dan kriteria pengenaannya untuk memberikan kepastian hukum dan SE-02/PJ/2008 terkait komponen penghitungan tarif PPh Pasal 15 karena dianggap sudah tidak relevan dengan kondisi saat ini. Hasil pemeriksaan pajak pun menunjukkan bahwa fiscus sulit menemukan bukti yang memperkuat dugaan terjadinya penghindaran pajak dengan memanfaatkan pembentukan Kantor Perwakilan Perusahaan Asing.

\section{IMPLIKASI DAN KETERBATASAN}

Pembahasan secara mendalam dengan pendekatan treaty masing-masing negara dalam penentuan karakteristik yang lebih tepat bagi suatu kantor perwakilan asing di Indonesia belum dilakukan dalam penelitian ini. Penelitian berikutnya dapat diperdalam tentang kajian mengenai skema ideal terkait pemajakan representative office baik dari segi tarif maupun modelnya.

\section{PENGHARGAAN (ACKNOWLEDGEMENT)}

Penulis ingin mengucapkan terima kasih yang sebesar-besarnya kepada narasumber, yaitu Made Widyartha dari KPP Badora, Ardian Rulli, Teguh Dwi Santoso, Anang Mury Kurniawan, Eko Wibowo, Rio Nugraha, Samudera Utama, Wisamodro Jati, Andreas Adoe dan Adi Saputra Marja yang telah berkenan dan mau memberikan kesempatan dan waktunya untuk menjadi narasumber bagi penulis.

\section{DAFTAR PUSTAKA}

Achtar, M.Z. (1994). Beberapa Catatan Hukum dari Kegiatan Representative Office di Indonesia. Jurnal Hukum dan Pembangunan, vol.24, No.4 Tahun 1994.

Badan Koordinasi dan Penanaman Modal (2021). Peraturan Kepala BKPM Nomor 15 Tahun 2015 Tentang Pedoman dan Tata Cara Perizinan dan Nonperizinan Penanaman Modal. Website: https://www.bkpm.go.id/en/ppid/generalinformation (diakses 16 Mei 2021)

Cheung, D. K., \& Jiang, Z. (2013). Contemporary Issues of Taxation of Representative Offices in China. Int'I Tax J., 39, 39.

Government of India. Taxation of Representative Offices.http://www.archive.india.gov.in/busi ness/taxation/representative.php (diakses 16 Mei 2021)

Gunadi. (2007). Pajak Internasional. Jakarta: Lembaga Penerbit Fakultas Ekonomi, Universitas Indonesia.

Inland Revenue Authority of Singapore. (2021) Area Representative Scheme. Website: https://www.iras.gov.sg/irashome/Individua Is/Locals/Working-Out-Your-Taxes/Specialtax-schemes/Area-Representative-Scheme/ (diakses 26 Juni 2021)

Kurniawan, A.M. (2017). Pokok Pokok Tax Treaty Panduan Praktis Interpretasi 
Persetujuan Penghindaran Pajak Berganda (P2B).

Jakarta: Mitra Wacana Media.

Kusuma, Z. P. (2019). Kedudukan dan kewenangan

Kantor Perwakilan Perusahaan Asing (KPPA)

dalam rangka Penanaman Modal Asing di

Indonesia (Doctoral dissertation, Universitas Airlangga).

Neuman, W.L. (2014). Social Research Methods: Qualitative and Quantitative Approaches.

Needham Heights: A Viacom Company.

OECD (2013) OECD Model Tax Convention: Revised Proposals Concerning The Interpretation and Application of Article 5 (Permanent Establishment)

Pengadilan Pajak (2021). Risalah Putusan Pengadilan Pajak. Retrieved from the Sekretariat Pengadilan [ajak Website: http http://www.setpp.kemenkeu. go.id/risalah

Pinto, D. (2006). The Need to Reconceptualize the Permanent Establishment Threshold. Bulletin for International Taxation 60 (7): 266-279

Sekaran, U., \& Bougie, R. (2016). Research methods for business: A skill building approach. John Wiley \& Sons.

Skaar, A (1991) Permanent Establishment: Erosion of a Tax Treaty Principle. The Netherlands: Kluwer Law Internasional

Tarsingot, M. (2014). Pendirian Kantor Perwakilan dan/atau Cabang di Indonesia oleh Perusahaan Berbadan Hukum Asing sebagai Bentuk Penanaman Modal Asing Dikaitkan dengan UU Nomor 25 Tahun 2007 tentang Penanaman Modal (Doctoral dissertation, Universitas Padjadjaran).

Thailand Board of Investment. 2021. What You Need to Know About Setting up a Business in Thailand

http://www.boi.go.th/index.php?page=setti ng_up_a_business (diakses 16 Mei 2021)

USBC. 2010. China Tightens Restrictions on Foreign Representative Offices. Website: https:// www.chinabusinessreview.com/china-tightensrestrictions-on-foreign-representative-offices/ (diakses 16 Mei 2021). 


\section{LAMPIRAN}

Tabel 1 Putusan Pengadilan Pajak atas PPh Pasal 15 atas Kantor Perwakilan Asing

\begin{tabular}{|c|l|c|r|}
\hline No & \multicolumn{1}{|c|}{ Putusan Pengadilan } & Keputusan & Nilai yang dikabulkan \\
\hline 1 & Put.76033/PP/M.VIA/27/2016 & Menolak & \\
\hline 2 & Put.77304/PP/M.IIIA/27/2016 & Mengabulkan Seluruhnya & Rp2.469.876.662 \\
\hline 3 & Put.73314/PP/M.IIIB/27/2016 & Mengabulkan Seluruhnya & Rp962.531.309 \\
\hline 4 & Put.70628/PP/M.VIIIB/27/2016 & Mengabulkan Seluruhnya & Rp4.032.730.436 \\
\hline 5 & Put.74044/PP/M.VIA/27/2016 & Mengabulkan Seluruhnya & Rp2.360.379.682 \\
\hline 6 & Put-71293/PP/M.VIIIB/27/2016 & Mengabulkan Seluruhnya & Rp261.826.505 \\
\hline
\end{tabular}

Sumber: Pengadilan Pajak (diolah) 